\title{
Environmental factors contributing to the development of brown muscle disease and perkinsosis in Manila clams (Ruditapes philippinarum) and trematodiasis in cockles (Cerastoderma edule) of Arcachon Bay
}

\author{
Binias Cindy ${ }^{1}$, Do Van Tu ${ }^{1}$, Jude-Lemeilleur Florence ${ }^{1}$, Plus Martin ${ }^{2}$, Froidefond Jean-Marie ${ }^{1}$, \\ De Montaudouin Xavier ${ }^{1,}$
}

${ }^{1}$ Univ Bordeaux 1, CNRS, UMR EPOC 5805, F-33120 Arcachon, France.

${ }^{2}$ IFREMER, LER AR, Arcachon, France.

* Corresponding author : email address : x.de-montaudouin@epoc.u-bordeaux1.fr

\begin{abstract}
:
The aim of the present study was to identify environmental factors that could explain the distribution of different pathologies of commercially exploited intertidal bivalves in an Atlantic lagoon, Arcachon Bay. In particular, the role of the salinity gradient as a driver was explored. The Manila clam Ruditapes philippinarum experienced two severe pathologies, perkinsosis, which is due to a protozoan parasite, and brown muscle disease (BMD), the etiological agent of which remains unknown. Perkinsus olseni infection was very low in a small low-salinity area but, at the scale of the entire lagoon, was more influenced by organic matter content in the sediment and by emersion time. BMD prevalence was also 2.6 times higher in the higher organic content area but was also negatively correlated with salinity. The sympatric cockle (Cerastoderma edule) was affected by eight trematode species. These parasites have a complex life cycle that generally involves three free-living host species. The distribution of the different trematode communities was rather patchy within Arcachon Bay with no clear relationship with measured environmental factors. The dominance of particular trematode species could be due to the presence of other hosts involved in their life cycle, making it more difficult to detect a major environmental driver. This survey demonstrated that salinity is not a major factor explaining disease distribution in this temperate lagoon. This result has consequences for the research of 'refuge areas' (free of diseases) or 'hot spots' (heavy infection) for species of high economic value.
\end{abstract}

Keywords : Arcachon bay, bivalves, diseases, distribution, parasites 
In coastal ecosystems, salinity is generally a strong driver of community structure (Blanchet et al. 2005). This is particularly true in systems such as estuaries where the gradient is obvious (Wolff 1973; Ysebaert \& Herman 2002; Rybarczyk \& Elkaim 2003). Typically, three types of faunal communities are encountered and these are associated with euhaline, polyhaline, mesohaline and oligohaline waters respectively. All of these have both pelagic (Herman et al. 1968; Orsi \& Mecum 1986; Baretta \& Malschaert 1988; David et al. 2006) and benthic components (Attrill \& Rundle 2002; Ysebaert \& Herman 2002). Parasite species may also display strong relationships to salinity gradients when their life cycles involve free-living stages sensitive to water mass characteristics. This has been described in protozoans like Perkinsus spp. that parasitize numerous mollusc species (Ahn \& Kim 2001; La Peyre et al. 2006). When the host dies, the parasite transforms into a stage, the hypnospore, that spends some time in the water before being inhaled by a new host (Choi \& Park 2010). The various species of the genus Perkinsus are known to be limited by low salinity (Leite et al. 2004). Most trematode species also display free-swimming larval stages in their life cycles, usually including two such stages. The parasite reproduces sexually in the definitive host. Eggs are emitted into the water with faeces and develop into miracidium larvae that infect the first intermediate host, always a mollusc. Asexual reproduction in this host leads to the formation of a new type of larvae, cercariae, which are shed into the water and swim or drift before infection of the second intermediate host. There, larvae remain in a latent stage, the metacercariae, and wait for their host to be preyed upon by the final host in order to complete their life cycle. Many studies have demonstrated that these swimming larvae are sensitive to salinity (Mouritsen 2002; Koprivnikar et al. 2010), suggesting that this factor could contribute to explaining the structure of parasite communities. 
In lagoons, however, salinity gradients are not always so pronounced and other structuring factors may interfere with the process. These include emersion rate, seagrass occurrence, and sediment grain size (Bachelet et al. 1996; Marzano et al. 2003; Blanchet et al. 2004). This results in a mosaic of communities where the major structuring factors are not always easy to detect. In relation to parasites, there is little knowledge on the factors that drive their distribution in these sheltered areas. For fishermen, such knowledge could contribute to identifying 'refuge areas' that are more or less exempt from infectious diseases (Hoffmann et al. 2009).

Arcachon Bay is a good system to illustrate and study these questions. It is a typical tidal lagoon with a cape sheltering most of the system and with freshwater inputs. Previous studies performed on free-living intertidal fauna demonstrated that the salinity gradient was not the only driver of the distribution of pelagic (Vincent 2002) and benthic communities (Bachelet \& Dauvin 1993; Blanchet et al. 2004). Arcachon Bay also supports the highest production of Manila clam Ruditapes philippinarum in France and periodically sustains a small cockle (Cerastoderma edule) fishery also. Both bivalves undergo pathologies. Perkinsosis (Perkinsus olseni) is very prevalent in Manila clams in the whole bay, with no detected gradient (Dang et al. 2010). Recently, in 2005, a new disease of the bivalve, Brown Muscle Disease (BMD), was described for the first time (Dang et al. 2008). The infectious agent is still unknown, although a virus is suspected (Dang et al. 2009). Finally, trematodes are abundant, mostly in cockles. An assemblage of 13 trematode species was identified in previous studies (Desclaux et al. 2002; de Montaudouin et al. 2009) but the distribution of these parasites at the lagoon scale remains unknown. Trematodes induce a less severe impact on their cockle hosts than that observed in Manila clams infected with Perkinsosis and BMD, except when the intensity (number of parasite individuals per infected host (Bush et al. 1997)) becomes high in cockles 
infected as second intermediate hosts (Desclaux et al. 2004) or when the cockle is the first intermediate host (Jonsson \& André 1992; Thieltges 2006).

Our specific aims were: 1) to describe a series of biotic and abiotic factors in Arcachon Bay in order to identify homogeneous entities, i.e. groups of stations that were defined by similar environmental characteristics with (salinity, temperature, emersion rate, grain-size median, seagrass biomass); 2) to assess levels of infection in cockles and clams; and 3) to identify environmental factors correlated with the various diseases. The general aim was to explore whether it is possible to identify 'hot spots' (accumulation of infections) or 'refuge areas' (sites free of pathogens) by measuring biotic and/or abiotic factors.

\section{Study site}

Arcachon Bay $\left(44^{\circ} 40^{\prime} \mathrm{N}, 1^{\circ} 10 \mathrm{~W}\right.$ ) is a macrotidal (tidal range $=0.9-4.9$ ) coastal lagoon situated on the South Western coast of France. This $156-\mathrm{km}^{2}$ ecosystem is connected to the Atlantic Ocean by a 2-3-km wide and 12-km long channel. Channels represent $41 \mathrm{~km}^{2}$ of the lagoon surface and penetrate between large intertidal areas $\left(115 \mathrm{~km}^{2}\right)$. A significant proportion of these tidal flats $\left(46 \mathrm{~km}^{2}\right)$ is covered by Zostera noltii seagrass beds (Plus et al. 2010). Arcachon Bay receives freshwater inputs from the North-East and south but mainly from a river (Leyre) located in the South-Eastern end of the lagoon. The balance between marine and freshwater inputs and the slow renewal of water by tides induce salinity and temperature gradients (Robert et al. 1987).

\section{Materials and Methods}

\section{Sampling procedure}

In October and November 2009, a total of 39 stations were sampled along two axes (i.e. two subareas) drawn between the most seaward part of the lagoon and the most landward, within 
the Manila clam and cockle habitats (Fig. 1). Stations were sampled at low tide. Six $0.25-\mathrm{m}^{2}$ quadrats were sampled by hand to collect clams and cockles. When the number of collected individuals was insufficient, additional individuals were collected haphazardly in the immediately surrounding area. After all stations had been sampled, we selected 28-36-mm shell length individuals, a length range that was common to all stations, for further analysis. Sediment was sampled for analysis of organic matter and median grain-size. Pictures were taken for analysis of seagrass biomass (see below) using a Fujifilm FinePix S9500 camera at a resolution of $1600 \times 1200$ pixels.

\section{Environmental factors}

Grain size and organic matter

At each station, the upper $3 \mathrm{~cm}$ of sediment was collected and subsequently analysed for grain-size distribution (wet sieving) and organic matter (loss of weight of dry sediment at $450^{\circ} \mathrm{C}$ for $\left.4 \mathrm{~h}\right)$.

\section{Biomass of seagrass foliage}

A rapid but reliable method of assessing the biomass of Zostera noltii leaves was developed for this study, during a preliminary sampling trip. Fifteen $15 \mathrm{~cm}$ x $15 \mathrm{~cm}$ quadrats were delicately laid over the sediment surface at low tide. These quadrats were visually selected to represent a large range of vegetation cover, from $0 \%$ (bare sediment) to $100 \%$. For each quadrat, a numerically identified photograph was taken from directly overhead, one meter above the surface.

Then, all leaves in the quadrat were cut at their base with scissors. Back at the lab, each sample was washed, weighed (fresh weight) and dried at $60^{\circ} \mathrm{C}$ for 48 hours to obtain a dry weight. 
On each photograph, polygons corresponding to bare sediment were drawn using image analysis software. The surface of these polygons was automatically calculated and the seagrass cover was deduced from the quadrat surface. The leaf dry weights and the surface covers were correlated following logarithmic transformation of both variables (and after removing one picture without grass). The relationship was described by the following equation:

$\ln (\mathrm{DW})=1.450 \times \ln (\mathrm{S})-1.733$, with $\mathrm{R}=0.98(\mathrm{n}=14$ pictures $)$

where $\ln (\mathrm{S})=0.690 \times \ln (\mathrm{DW})+1.195$

DW is Zostera noltii leaves dry weight in $\mathrm{g}^{-\mathrm{m}^{-2}}$ and $\mathrm{S}$ is the $\%$ of sediment covered by $\mathrm{Z}$. noltii. The biomass in fresh weight (FW) could also be obtained

$\mathrm{FW}=13.2 \times \mathrm{DW}, \mathrm{R}^{2}=0.95(\mathrm{n}=15)$

Therefore from a numerically identified picture, it was possible to obtain a biomass with reliable precision. This method was more precise for lower seagrass covers; as vegetation cover approaches $100 \%$, the method becomes less precise because $100 \%$ cover may correspond to many biomass values, depending on seagrass bed thickness.

The drawing of polygons allowed us to obtain the relationship between leaf biomass and seagrass cover but was highly time consuming for routine survey. Consequently, we used a line-drawing method in order to estimate foliage biomass more rapidly. This method consisted of drawing three equidistant lines across each numerical image and counting the intersections between lines and leaves. The $15 \mathrm{~cm}$ x $15 \mathrm{~cm}$ frame was placed with leaves perpendicular to one of the square sides and lines were drawn at right angle to leaves. The best correlations were found after logarithmic transformation of both variables (intersection and biomass) and described as follows;

$\ln (\mathrm{DW})=1.514 \times \ln ($ mean number of intercepts per line $)-1.9113$, with $\mathrm{R}=0.98(\mathrm{n}=14)$ 
This method was utilized to determine aerial biomass in the 39 investigated stations (10 frames per station). Less than ten minutes per photograph, including line drawing, were necessary to estimate aerial biomass.

Temperature, salinity, emersion time

Temperature, salinity and emersion rates for each sampling site were obtained by means of a mathematical model (MARS, (Lazure \& Dumas 2008)), that had been previously applied and validated on Arcachon Bay (Plus et al. 2009). This three-dimensional hydrodynamic model calculates free surface height variations, current speed and direction, water temperature and salinity, at a $235 \mathrm{~m}$ resolution on the horizontal plane (10 meshes on the vertical) and at time steps ranging from 10 to 60 seconds. The model was launched for a three year period (November 2006 to November 2009), and the following parameters were recorded for each site:

- Temperature and salinity minima, maxima and means.

- Percent of time spent in emersion.

- Frequency histograms for temperature (percent of time spent at temperatures below the following thresholds: $8,12,16$ and $20^{\circ} \mathrm{C}$ ). These threshold values cover the range of values that is found in this area and allow detecting particularly low and high temperatures from "rare events".

- Frequency histograms for salinity (percent of time spent at salinities below the following thresholds: 13, 28 and 34). These threshold values cover the range of values that is found in this area and allow detecting particularly low and high salinities from "rare events". 
Boundary conditions were provided by the global tidal solution FES99 (Lefèvre et al. 2002) and the atmospheric forcing parameters - air temperature, atmospheric pressure, nebulosity, relative humidity and surface wind stress - were provided by the ARPEGE model (MétéoFrance).

Comparisons between available ground-truth values and model simulations were performed in order to validate the mathematical model for the study period (from November 2006 to November 2009). Empirical temperature and salinity data were taken from the ARCHYD database (Ifremer), selecting four stations located along the clam sampling axes (Fig. 1). Sea surface height ( $\mathrm{SSH}$ ) observations at the Eyrac tide gauge (Fig. 1) were provided by the REFMAR website (refmar.shom.fr) and remain the property of the SHOM (Naval Hydrographic and Oceanographic Service) and the Gironde DDTM (Sea and Territory Departmental Directorate). Model evaluation was performed following Piñeiro et al. (2008), regressing observed vs. predicted values and testing the significance of slope $=1$ and intercept $=0$. This analysis was complemented by RMSD (root mean squared deviation) and EFF (model efficiency) calculations:

$$
R M S D=\sqrt{\frac{\sum_{i=1}^{n}\left(Y_{i \text { mod }}-Y_{\text {iobs }}\right)^{2}}{n}} \quad E f f=1-\frac{\sum_{i=1}^{n}\left(Y_{i \text { mod }}-Y_{\text {iobs }}\right)^{2}}{\sum_{i=1}^{n}\left(Y_{\text {iobs }}-\bar{Y}_{\text {obs }}\right)^{2}}
$$

where $Y_{\text {imod }}$ and $Y_{\text {iobs }}$ are respectively the predicted and observed values and $n$ is the total number of values.

Table 1 summarizes the results of the model validation. Observed vs. predicted values regressions showed that the model behaved satisfactorily. Best model performances were obtained for sea surface elevation and temperature, with a very high percentage of variance in observed values explained by the model (respectively $97 \%$ and 98\%). The worst model performance was obtained for salinity but the coefficient of determination still remains high $(85 \%)$. All tests for slope $=1$ and intercept $=0$ were passed and model efficiency was near 1 . 
Theil's partial coefficients show that most of the errors in model predictions were due to unexplained variance and not to bias or to misleading. Temperature, salinity and SSH root mean squared deviations were $0.78^{\circ} \mathrm{C}, 0.79$ and $19 \mathrm{~cm}$, respectively.

\section{Bivalve models and associated pathology}

Manila clam and Perkinsus

All collected Manila clams (Ruditapes philippinarum) belonging to shell length class 28-36 mm were opened (34 stations out of 39 investigated stations harboured Manila clams with adequate shell length) and gill samples were excised. Five gills from clams with identical lengths were pooled and weighed for analyses of Perkinsus infection levels as determined by the FTM (fluid thioglycolate medium) assay (Ray 1966). Depending on clam availability, between 2 and 6 pools (except 1 pool in a single station $\left(n^{\circ} 21\right)$ ) were obtained. For induction of prezoosporangia (hypnospores), gill samples were placed in separate $15 \mathrm{~mL}$ tubes containing $9.5 \mathrm{~mL}$ FTM supplemented with $66 \mu \mathrm{g} \mathrm{mL}^{-1}$ streptomycin, $32 \mu \mathrm{g} \mathrm{mL}^{-1}$ penicillin $\mathrm{G}$ and, $40 \mu \mathrm{g} \mathrm{mL}^{-1}$ nystatin (final concentrations), to prevent bacterial and fungal activity. The tubes were incubated at room temperature for 7 days, in the dark. After incubation, the samples were stored at $4^{\circ} \mathrm{C}$ until hypnospore enumeration. To lyse tissues, samples were centrifuged at $2500 \mathrm{rd} / \mathrm{min}(664 \mathrm{~g})$ for $10 \mathrm{~min}$. Pellets were added with $5 \mathrm{~mL} 2 \mathrm{~N} \mathrm{NaOH}$, and incubated at $60^{\circ} \mathrm{C}$ for at least 1 hour. This step was repeated before pellets were rinsed twice with $10 \mathrm{~mL} 0.1 \mathrm{M}$ phosphate-buffered saline (PBS). Final pellets were resuspended in $1 \mathrm{~mL}$ PBS and hypnospores were counted twice using a Malassez counting chamber.

The concentration of Perkinsus was correlated to the different variables of the environment (Pearson correlation, after verifying normality of residuals), and was compared among the 
four spatial groups (Kruskal Wallis test due to heteroscedasticity) and between the two axes, i.e. between the two subareas of the lagoon (Student $t$-test) (Statistica 7 software).

\section{Manila clam and BMD}

All collected clams belonging to the $28-36-\mathrm{mm}$ shell length class were opened and an index of the pathology (Muscle Print Index, MPI) estimated. On the posterior adductor muscle (the only affected one), the MPI was used to designate the surface colonized by the brown muscle print on a scale of 0 to 4 as follows: 0 (healthy), 1 (0-25\%), $2(25-50 \%), 3(50-75 \%)$ and 4 (75-100\%). When both valves displayed different pathology indices, the highest category was selected to characterize the stage of BMD. Prevalence was defined as the percentage of infected hosts (Bush et al. 1997).

\section{Cockles and trematodes}

When possible, five cockles between 13 and 29-mm shell length per station were opened. The flesh was separated and squashed between two large glass slides. Trematodes were identified and counted under a stereomicroscope (de Montaudouin et al. 2009). Trematode abundance was defined as the mean number of metacercariae per individual host, and prevalence as the percentage of infected hosts (Bush et al. 1997). A correspondence analysis was performed on data which consisted of a '35 stations x 8 trematode species' matrix when each species occurred. Data (averaged metacercariae abundance) were $\log _{10}(x+1)$ transformed. In the case of Bucephalus minimus, it was not possible to separate and count sporocysts and a value of 1 was arbitrarily imposed in the matrix. Particular attention was devoted to the identification of the 'contributive' taxa. A taxon was considered 'contributive' when its contribution to the dimension's inertia was at least twice the mean theoretical contribution of a taxon. 
Considering that the 8 taxa of the matrix contributed to $100 \%$ inertia, a "contributive" taxon inertia should arbitrarily be over (100/8) x $2=25 \%$.

\section{Results}

\section{Environmental factors}

The Principal Component Analysis separated 4 spatial groups (Fig. 1A). Group 1 isolated a small number of stations at the mouth of the two freshwater inputs (Canal des Etangs and Leyre) (Fig. 1B). This group was characterized by low mean salinity (22.6), high frequency of $\mathrm{T}<16^{\circ} \mathrm{C}(50 \%)$, high organic matter and silt and clay contents in the sediment (7.8 and $38.5 \%$, respectively), null emersion time, and low seagrass coverage (7\%) (Table 2). Group 2 gathered stations in oceanic position with high median grain size $(191 \mu \mathrm{m})$, high mean salinity (32.8), mean temperature similar to elsewhere in the lagoon $\left(17^{\circ} \mathrm{C}\right)$ but with low occurrence of cold events, i.e. low frequency of $\mathrm{T}<8^{\circ} \mathrm{C}(4.2 \%)$, low organic matter and silt and clay content in the sediment (3.2 and 16.3\%, respectively) (Fig. 1) (Table 2). Groups 3 and 4 displayed medium mean salinity (30.1), medium frequency of $\mathrm{T}<8^{\circ} \mathrm{C}(7.7 \%)$ (Table 2). Axis 2 displayed a higher percentage of silt and clay, organic matter in the sediment and emersion time and more extreme water temperatures than Axis 1 (Table 3).

\section{Manila clam and Perkinsosis}

The mean concentration of Perkinsus in the bay was 62,000 cells.g $^{-1}$ (gill fresh weight FW) and could reach 209,000 cells.g ${ }^{-1}$ (gill FW) (station 33, Axis 2, Fig. 2). It was positively correlated to organic matter concentration in the sediment, percentage of emersion, and distance to Leyre River and was negatively correlated to frequency of $\mathrm{T}<16^{\circ} \mathrm{C}$ and distance to Canal des Etangs (Table 4). There was a significant difference of Perkinsus concentration among spatial groups (Kruskal Wallis, $\mathrm{df}=3, \mathrm{H}=22.58$, p<0.001), Group 1 (7,400 cells.g ${ }^{-1}$ (gill 
FW)) being different from Groups 2, 3 and 4 that displayed similar infection (70,193 cells. $\mathrm{g}^{-1}$ (gill FW)). Perkinsus abundance was three times higher in Axis $2\left(\right.$ mean $=95,701$ cells.g $^{-1}$ gill fresh weight) than in Axis 1 (mean $=28,917$ cells. $\mathrm{g}^{-1}$ gill fresh weight) (Student $t$-test, $\mathrm{df}=33$, $t=-4.62, \mathrm{p}<0.001)$.

\section{Manila clam and Brown Muscle Disease}

The mean Brown Muscle Disease (BMD) prevalence per station in Manila clams throughout the bay was $11 \%$ (Fig. 3). BMD prevalence and Muscle Print Index (MPI) were positively correlated with silt and organic matter contents in the sediment and with salinity frequency $\mathrm{S}<34$. They were negatively correlated with minimal temperatures. Besides, MPI was positively correlated with mean water temperature and with Manila clam density (Table 4). However, the influence of freshwater input was not similar between Canal des Etangs and Leyre. There was no difference of prevalence between spatial groups (one-way ANOVA, $\mathrm{F}_{3,28}=2.03, \mathrm{p}=0.13$ ). However, Muscle Print Index increased from the most oceanic spatial group $(\mathrm{G} 2)\left(\mathrm{MPI}_{\text {mean }}=0.8\right)$ to the more continental ones $(\mathrm{G} 3$ and $\mathrm{G} 4)\left(\mathrm{MPI} \mathrm{I}_{\text {mean }}=2.4\right)$ groups (one-way ANOVA, $\mathrm{F}_{3,28}=11.74, \mathrm{p}<0.001$ ). Prevalence was 2.6 times higher along Axis 2 (16.1\%) (See Fig. 1 for localisation of both axes) than along Axis 1 (4.5\%) (U-Mann \& Whitney, $\mathrm{Z}=-2.70, \mathrm{p}=0.007$ ) (Fig. 3). MPI was similar in both axes (1.84) (U-Mann \& Whitney, $\mathrm{Z}=-1.55, \mathrm{p}=0.12$ ).

\section{Cockles and trematodes}

Cockles were present in 35 stations out of the 39 stations investigated. A total of eight trematode taxa were found. Seven species utilize the cockle as second intermediate host. One of them belongs to the genus Himasthla and could be a complex of two species, $H$. quissetensis and H. continua. The $8^{\text {th }}$ species, Bucephalus minimus, utilizes the cockle as first 
intermediate host with a global prevalence of $13 \%$ ( $\mathrm{N}=144$ cockles). Dimension 1 of the Correspondence Analysis (44.6\% of inertia) discriminated H. interrupta whereas dimension 2 (23.6\% inertia) discriminated Curtuteria arguinae and $H$. spp. (Fig. 4A). Three trematode communities can be identified in the bay (Fig. 4B): 1) H. interrupta was present in the northern part of the bay only (mean abundance per station was comprised between 3 and 22 metacercariae.cockle ${ }^{-1}$ ) and was accompanied by a high B. minimus prevalence (24\% with $\mathrm{N}=25$ cockles) ; 2) Curtuteria arguinae was the dominant trematode in the south-west end of the bay, i.e. the most oceanic part (mean abundance per station comprised between 9 and 43 metacercariae.cockle ${ }^{-1}, \mathrm{~N}=34$ cockles), often accompanied by Diphterostomum brusinae; 3) the south-eastern end of the bay was characterized by a higher abundance in $H$. spp. (mean abundance per station comprised between 9 and 43 metacercariae.cockle ${ }^{-1}, \mathrm{~N}=34$ cockles) that represented the only trematode taxon present there .

\section{Discussion}

The aim of the study was to correlate the distribution of three types of bivalve diseases within a lagoon (Arcachon Bay) in order to identify the main drivers. Salinity is often cited as a strong contributing factor (Ahn \& Kim 2001; Elandalloussi et al. 2008) but many confounding factors may intervene along the gradient. The unusual feature of Arcachon Bay was the presence of two major freshwater inputs that induce a bi-directional salinitytemperature gradient, East-West and North-South. We demonstrated that the effect of salinity was restricted to a very narrow area around the mouth of the river, for perkinsosis only. Indeed, Perkinsus concentration was significantly lower than elsewhere in Group 1 only, corresponding to 3 stations near river mouths. The distribution of all diseases was explained less within "oceanic vs. continental" axis than between both northwest and southwest subareas of the lagoon. This suggests that factors other than salinity were contributing. 
The Principal Component Analysis discriminated groups of stations in accordance with what could be expected in such an ecosystem: an oceanic-influenced group (Group 2), a continentinfluenced group (Group 1) and two intermediates groups (Groups 3 and 4) (Bouchet 1993). The mean abundance of perkinsosis infection was high compared to previous studies (Lassalle et al. 2007) but was lower than that assessed in Arcachon Bay in 2006 (96,000 cells.g ${ }^{-1}$ (gill FW) (Dang et al. 2010). This difference can be explained by the distribution of sampling stations, which in the present study took into account a broader area including stations with low infection. Salinity is an important factor structuring the abundance of Perkinsus spp. in some locations (Leite et al. 2004). For P. olseni, the optimal salinity range is 25-35 (Auzoux-Bordenave et al. 1995) and high infection generally corresponds to high salinity (Burreson \& Ragone Calvo 1996; Cigarría et al. 1997; Park \& Choi 2001). In Arcachon Bay a similar gradient was formerly obtained (Dang et al. 2010) but mainly due to stations sampled near freshwater inputs. In the present study, the refuge function of lowsalinity areas was evident (Group 1), but concerned less than 5\% of the axis lengths. It should be determined if these low salinity areas are effective for commercially relevant growth rates in the shellfish. The salinity gradient out of these areas was not high enough to induce a perkinsosis infection gradient. Unexpectedly, the highest difference in perkinsosis infection was observed between Axes 1 and 2. The environmental characteristics that were significantly different between axes involved sediment and emersion. The highest content in silt and clay, and organic matter in the sediment coincided with the highest emersion rate, the highest extreme temperatures and eventually the highest perkinsosis infection (Axis 2). Higher infection in muddy sediment than in sands was already reported (Choi et al. 2002). Our hypothesis is also that the highest emersion rate (higher average hypsometric level) is due to (and/or is the consequence) a smaller input of oceanic water during flood-tides, a lower water turn-over and a higher sedimentation of fine particles. This lower turn-over is consistent with 
an unpublished report that $1 / 3$ of the water mass transits through Axis 2 against $2 / 3$ through Axis 1 (SOGREAH 2001). That would increase the retention of Perkinsus hypnospores and facilitate infection between clams.

A similar observation was made with Brown Muscle Disease (BMD). Interpretation is more difficult due to the lack of knowledge concerning the infectious agent which might be a virus (Dang et al. 2009). Here again, Axis 2 displayed higher prevalence in relation to sediment characteristics (but similar Muscle Print Index (MPI)). This axis was also characterized by higher clam densities $(+60 \%$, although $\mathrm{p}>0.05)$ which could facilitate disease transmission.

The situation of trematodes was different because many species were involved and the distribution corresponded to a community analysis pattern. At the lagoon scale, three communities were discriminated by one or two dominant trematode species, and these were related to the presence of their other hosts (Sapp \& Esch 1994; Hechinger \& Lafferty 2005; Byers et al. 2008), the first intermediate and definitive hosts, which are sensitive to environment characteristics. Trematode communities were also different between the two areas of freshwater input (Leyre River and Canal des Etangs).

Our analyses were all correlative. Relationships between causes and consequences were not demonstrated but the identification of two different sub-ecosystems arose, independently of salinity gradient. For Manila clams, the notion of 'refuge' concerns a very small area and is not relevant for BMD. Hence, this is not interesting in terms of fishery management. However, the difference in infection between the two axes is important and suggests that fisheries models should be developed by subareas and not at the whole ecosystem scale (Bald et al. 2009). Trematode communities in cockles have a patchy distribution but the level of infection remained low compared to known pathological thresholds (Desclaux et al. 2004; Gam et al. 2009) and should, therefore, have a low impact in this system. 


\section{Acknowledgements}

Warm thanks are due to Pascal Lebleu, Francis Prince, Laurent Letord and Benoît Gouillieux for their assistance in sampling during difficult, cold, muddy and wet walks across the Bay. Many thanks to Sarah Culloty for correcting the English. This study was financed by Programme LITEAU 3 of the French Environment Ministry (Project REPAMEP).

\section{Literature cited}

Ahn K.J., Kim K.H. (2001) Effect of temperature and salinity on in vitro zoosporulation of Perkinsus sp. in Manila clams Ruditapes philippinarum. Diseases of Aquatic Organisms, 48, 43-46.

Attrill M.J., Rundle S.D. (2002) Ecotone or ecocline: ecological boundaries in estuaries. Estuarine, Coastal and Shelf Science, 55, 929-936.

Auzoux-Bordenave S., Vigario A.M., Ruano F., Domart-Coulon I., Doumenc D. (1995) In vitro sporulation of the clam pathogen Perkinsus atlanticus (Apicomplexa, Perkinsea) under various environmental conditions. Journal of Shellfish Research, 14, 469-475.

Bachelet G., Dauvin J.-C. (1993) Distribution quantitative de la macrofaune benthique des sables intertidaux du Bassin d'Arcachon. Oceanologica Acta, 16, 83-97.

Bachelet G., de Montaudouin X., Dauvin J.-C. (1996) The quantitative distribution of subtidal macrozoobenthic assemblages in Arcachon Bay in relation to environmental factors: a multivariate analysis. Estuarine, Coastal and Shelf Science, 42, 371-391.

Bald J., Sinquin A., Borja A., Caill-Milly N., Duclercq B., Dang C., de Montaudouin X. (2009) A system dynamics model for the management of the Manila clam, Ruditapes philippinarum (Adams and Reeve, 1850) in the Bay of Arcachon (France). Ecological Modelling, 220, 2828-2837.

Baretta J.W., Malschaert J.F.P. (1988) Distribution and abundance of the zooplankton of the Ems estuary (North Sea). Netherlands Journal of Sea Research, 22, 69-81.

Blanchet H., de Montaudouin X., Chardy P., Bachelet G. (2005) Structuring factors and recent changes in subtidal macrozoobenthic communities of a coastal lagoon, Arcachon Bay (France). Estuarine, Coastal and Shelf Science, 64, 561-576.

Blanchet H., de Montaudouin X., Lucas A., Chardy P. (2004) Heterogeneity of macrozoobenthic assemblages within a Zostera noltii seagrass bed: diversity, abundance, biomass and structuring factors. Estuarine, Coastal and Shelf Science, 61, 111-123.

Bouchet J.-M. (1993) Stratifications, fronts halins dans une lagune mésotidale (Bassin d'Arcachon - France). In: Sorbe J-C, Jouanneau J-M (eds) 3e Colloque International d'Oceanographie du Golfe de Gascogne. Station Marine d'Arcachon, Arcachon, p 3339

Burreson E.M., Ragone Calvo L.M. (1996) Epizootiology of Perkinsus marinus disease of osters in Chesapeake bay, with emphasis on data since 1985. Journal of Shellfish Research, 15, 17-34. 
Bush A.O., Lafferty K.D., Lotz J.M., Shostak A.W. (1997) Parasitology meets ecology on its own terms: Margolis et al. revisited. Journal of Parasitology, 83, 575-583.

Byers J.E., Blakeslee M.H., Linder E., Cooper A.B., Maguire T.J. (2008) Controls of spatial variation in the prevalence of trematode parasites infecting a marine snail. Ecology, 89, 439-451.

Choi H.-S., Park K.-I., Lee K.-W., Matsuoka K. (2002) Infection intensity, prevalence, and histopathology of Perkinsus sp. in the Manila clam, Ruditapes philippinarum, in Isahaya bay, Japan. Journal of Shellfish Research, 21, 119-125.

Choi K.-S., Park K.-I. (2010) Review on the protozoan parasite Perkinsus olseni (Lester and Davis 1981) infection in Asian waters. In: Ishimatsu A, Lie H-J (eds) Coastal Environmental and Ecosystem Issues of the East China Sea. TERRAPUB and Nagasaki University, Nagasaki, p 269-281.

Cigarría J., Rodrígues J.M., Fernández J.M. (1997) Impact of Perkinsus sp. on Manila clam Ruditapes philippinarum beds. Diseases of Aquatic Organisms, 29, 117-120.

Dang C., de Montaudouin X., Caill-Milly N., Trumbic Ž. (2010) Spatio-temporal patterns of perkinsosis in the Manila clam Ruditapes philippinarum from Arcachon Bay (SW France). Diseases of Aquatic Organisms, 91, 151-159.

Dang C., de Montaudouin X., Gonzalez P., Mesmer-Dudons N., Caill-Milly N. (2008) Brown Muscle Disease (BMD), an emergent pathology affecting Manila clam Ruditapes philippinarum in Arcachon bay (SW France). Diseases of Aquatic Organisms, 80, 219-228.

Dang C., Gonzalez P., Mesmer-Dudons N., Bonami J.R., Caill-Milly N., de Montaudouin X. (2009) Virus-like particles associated with Brown Muscle Disease in Manila clam (Ruditapes philippinarum) in Arcachon Bay (France). Journal of Fish Diseases, 32, 577-584.

David V., Chardy P., Sautour B. (2006) Fitting a predator-prey model to zooplankton timeseries data in the Gironde estuary (France): Ecological significance of the parameters. Estuarine, Coastal and Shelf Science, 67, 605-617.

de Montaudouin X., Thieltges D.W., Gam M., Krakau M., Pina S., Bazaïri H., Dabouineau L., Russell-Pinto F., Jensen K.T. (2009) Review - Digenean trematode species in the cockle Cerastoderma edule: identification key and distribution along the North-East Atlantic shoreline. Journal of the Marine Biological Association of the United Kingdom, 80, 543-556.

Desclaux C., de Montaudouin X., Bachelet G. (2002) Cockle emergence at the sediment surface: 'favourization' mechanism by digenean parasites? Diseases of Aquatic Organisms, 52, 137-149.

Desclaux C., de Montaudouin X., Bachelet G. (2004) Cockle (Cerastoderma edule) population mortality: the role of the digenean parasite Himasthla quissetensis. Marine Ecology Progress Series, 279, 141-150.

Elandalloussi L.M., Carrasco N., Roque A., Fernández-Tejedor M., Furones D. (2008) Occurence of Perkinsus sp. in two clam species (Ruditapes philippinarum and $R$. decussatus from the Ebro delta, Spain. Bulletin of the European Association of Fish Pathologists, 28, 1-9.

Gam M., de Montaudouin X., Bazaïri H. (2009) Do trematode parasites affect cockle (Cerastoderma edule) secondary production and elimination? Journal of the Marine Biological Association of the United Kingdom, 89, 1395-1402.

Hechinger R.F., Lafferty K.D. (2005) Host diversity begets parasite diversity: bird final hosts and trematodes in snail intermediate hosts. Proceedings of the Royal Society B, 272, 1059-1066. 
Herman S.S., Mihursky J.A., McErlean A.J. (1968) Zooplankton and environmental characteristics of the Patuxent River Estuary. Chesapeake Science, 9, 67-82.

Hoffmann E., Bushek D., Ford S., Guo X., Haidvogel D., Hedgecock D., Klinck J.M., Milbury C.A., Narvaez D., Powell E.N., Wang Y., Wang Z., Wilkin J., Zhang L. (2009) Understanding how disease and environment combine to structure resistance in estuarine bivalve populations. Oceanography, 22, 212-231.

Jonsson P.R., André C. (1992) Mass mortality of the bivalve Cerastoderma edule on the Swedish west coast caused by infestation with the digenean trematode Cercaria cerastodermae I. Ophelia, 36, 151-157.

Koprivnikar J., Lim D., Fu C., Brack S.H.M. (2010) Effects of temperature, salinity, and pH on the survival and activity of marine cercariae. Parasitology Research, 106, 11671177.

La Peyre M., Casas S.M., La Peyre J. (2006) Salinity effects on viability, metabolic activity and proliferation of three Perkinsus species. Diseases of Aquatic Organisms, 71, 59-74.

Lassalle G., de Montaudouin X., Soudant P., Paillard C. (2007) Parasite co-infection of two sympatric bivalves, the Manila clam (Ruditapes philippinarum) and the cockle (Cerastoderma edule) along a latitudinal gradient. Aquatic Living Resource, 20, 33-42.

Lazure P., Dumas F. (2008) An external-internal mode coupling for a 3D hydrodynamical model for applications at regional scale (MARS). Advances in Water Resources, 31, 233-250.

Lefèvre F., Lyard F.H., Le Provost C., Schrama E.J.O. (2002) FES99 : a global tide finite element solution assimilating tide gauge and altimetric information. Journal of Atmospheric and Oceanic Technology, 19, 1345-1356.

Leite R.B., Afonso R., Cancela M.L. (2004) Perkinsus sp. infestation in carpet-shell clams, Ruditapes decussatus (L), along the Portuguese coast. Results from a 2-year survey. Aquaculture, 240, 39-53.

Marzano C.N., Liaci L.S., Fianchini A., Gravina F., Mercurio M., Corriero G. (2003) Distribution, persistence and change in the macrobenthos of the lagoon of Lesina (Apulia, southern Adriatic Sea). Oceanologica Acta, 26, 57-66.

Mouritsen K.N. (2002) The Hydrobia ulvae - Maritrema subdolum association: influence of temperature, salinity, light, water-pressure and secondary host exudates on cercarial emergence and longevity. Journal of Helminthology, 76, 341-347.

Orsi J.J., Mecum W.L. (1986) Zooplankton distribution and abundance in the Sacremento-San Joaquin delta in relation to certain environmental factors. Estuaries, 9, 326-339.

Park K.-I., Choi K.-S. (2001) Spatial distribution of the protozoan parasite Perkinsus sp. found in the Manila clams, Ruditapes philippinarum, in Korea. Aquaculture, 203, 9-22.

Piñeiro G., Perelman S., Guerschman J.P., Paruelo J., (2008) How to evaluate models: Observed vs. predicted or predicted vs. observed? Ecological Modelling, 216, 316-322.

Plus M., Dalloyau S., Trut G., Auby I., de Montaudouin X., Emery E., Claire N., Viala C. (2010) Long-term evolution (1988-2008) of Zostera spp. meadows in Arcachon Bay (Bay of Biscay). Estuarine, Coastal and Shelf Science, 87, 357-366.

Plus M., Dumas F., Stanisière J.Y., Maurer D. (2009) Hydrodynamic characterization of the Arcachon Bay, using model-derived descriptors. Continental Shelf Research, 29, 1008-1013.

Ray S.M. (1966) A review of the culture method of detecting Dermocystidium marinum with suggested modifications and precautions. Proceedings of the National Shellfish Association, 54, 55-69.

Robert R., Guillocheau N., Collos Y. (1987) Hydrobiological parameters during an annual cycle in the Arcachon Basin. Marine Biology, 95, 631-640. 
Rybarczyk H., Elkaim B. (2003) An analysis of the trophic network of a macrotidal estuary: the Seine estuary (Eastern Channel, Normandy, France). Estuarine, Coastal and Shelf Science, 58, 775-791.

Sapp K.K., Esch G.W. (1994) The effects of spatial and temporal heterogeneity as structuring forces for parasite communities in Heliosoma anceps and Physa gyrina. American Midland Naturalist, 132, 91-103.

SOGREAH (2001) Bassin d'Arcachon - Amélioration de l'hydraulique réflexion sur la programmation des travaux. Report No. n71 1027 R, SOGREAH - Syndicat Intercommunal du Bassin d'Arcachon

Thieltges D.W. (2006) Parasite induced summer mortality in the cockle Cerastoderma edule by the trematode Gymnophallus choledochus. Hydrobiologia, 559, 455-461.

Vincent D. (2002) Dynamique et nutrition du zooplancton (Bassin d'Arcachon) : flux de carbone et d'azote associés. Conséquences sur le pool nutritif et sur les organismes. Université de la Méditerranée:

Wolff W.J. (1973) The estuary as a habitat: an analysis of data on the soft-bottom macrofauna of the estuarine area of the rivers Rhine, Meuse, and Scheldt. Zoologische Verhandelingen, 126, 1-242.

Ysebaert T., Herman P.M.J. (2002) Spatial and temporal variation in benthic macrofauna and relationships with environmental variables in an estuarine, intertidal soft-sediment environment. Marine Ecology Progress Series, 244, 105-124. 
Table 1. Regressions parameters (slope a and bias $\mathrm{b}$, for the $\mathrm{Y}_{\mathrm{obs}}=a \mathrm{Y}_{\mathrm{mod}}+b$ equation), coefficient of determination $\left(\mathrm{r}^{2}\right)$, Theil's partial inequality coefficients $\left(\mathrm{U}_{\text {bias }}, \mathrm{U}_{\text {slope }}\right.$ and $\mathrm{U}_{\text {error, }}$, are the proportions of observed variance not explained by the predicted values but due to respectively, mean differences between observed and predicted values, slope error and unexplained variance), root mean squared deviation (RMSD, expressed in the same units as the variables) and model efficiency (Eff, the closer Eff is to 1, the better is the model), for observed vs. predicted variables (temperature, TEMP, salinity, SAL and sea surface height, SSH).

\begin{tabular}{llll}
\hline & SSH & Temperature & Salinity \\
\hline $\mathrm{a}$ & 1.008 & 0.958 & 0.910 \\
Significance of test $\mathrm{a}=1$ & 0.20 & 0.09 & 0.18 \\
$\mathrm{~b}$ & 0.016 & 0.376 & 3.086 \\
Significance of test $\mathrm{b}=0$ & 0.33 & 0.35 & 0.16 \\
Degree of freedom & 915 & 34 & 34 \\
$\mathrm{r}^{2}$ & 0.97 & 0.98 & 0.85 \\
$\mathrm{U}_{\text {bias }}(\%)$ & 0.034 & 0.125 & 0.039 \\
$\mathrm{U}_{\text {slope }}(\%)$ & 0.002 & 0.071 & 0.049 \\
$\mathrm{U}_{\text {error }}(\%)$ & 0.964 & 0.804 & 0.912 \\
RMSD & 0.19 & 0.78 & 0.79 \\
EFF & 0.96 & 0.98 & 0.84 \\
\hline
\end{tabular}


Table 2. Different characteristics of the environment averaged for each of the four groups that were defined by the Principal Component Analysis (Fig. 2). ANOVA (F value) or Kruskal Wallis tests $(\mathrm{H})$ were performed to compare values among groups. Superscript letters gather groups that are similar for a given parameter, values that are different from values of the three other groups $(\mathrm{p}<0.05)$ are in bold and italic.

\begin{tabular}{|c|c|c|c|c|c|c|c|c|}
\hline & & Group 1 & Group 2 & Group 3 & Group 4 & $\mathrm{~F}$ & $\mathrm{H}$ & $p$ \\
\hline Sediment & $\begin{array}{l}\text { Median }(\mu \mathrm{m}) \\
\text { Silt }(\%) \\
\text { Organic matter } \\
(\%) \\
\text { Seagrass cover } \\
(\%)\end{array}$ & $\begin{array}{l}103^{\mathrm{b}} \\
\pm 52.8 \\
38.5^{\mathrm{a}} \\
\pm 11.3 \\
7.8^{\mathrm{bc}} \\
\pm 2.6^{\mathrm{b}} \\
6.2^{\mathrm{a}} \\
\pm 10.8\end{array}$ & 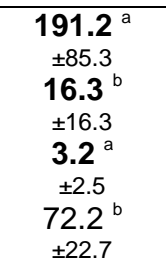 & $\begin{array}{c}96.5^{\mathrm{b}} \\
\pm 37.8^{\mathrm{a}} \\
38.8^{\mathrm{a}} \\
\pm 3.2^{\mathrm{a}} \\
9.1^{\mathrm{c}} \\
\pm 1.3 \\
40.1^{\mathrm{ab}} \\
\pm 23.4\end{array}$ & $\begin{array}{c}108.3^{\mathrm{b}} \\
\pm 22.5^{\mathrm{a}} \\
29.5^{\mathrm{a}} \\
\pm 8.3^{\mathrm{b}} \\
6.2^{\mathrm{b}} \\
\pm 2.5^{\mathrm{ab}} \\
44.9^{\mathrm{ab}} \\
\pm 26.7\end{array}$ & 7.91 & 13.23 & $<0.001$ \\
\hline Salinity & $\begin{array}{l}\text { Mean } \\
F<13 \\
F<28 \\
F<34\end{array}$ & $\begin{array}{c}22.5^{\mathrm{c}} \\
\pm 3.7^{\mathrm{a}} \\
16.4^{\mathrm{a}} \\
\pm 8.7^{\text {a }} \\
\mathbf{6 6 . 6} \\
\pm 19.0^{\mathrm{a}} \\
99.9^{\mathrm{a}} \\
\pm 0.0^{\mathrm{a}}\end{array}$ & $\begin{array}{c}32.8^{\mathrm{b}} \\
\pm 0.3^{\mathrm{b}} \\
0.0^{\mathrm{b}} \\
\pm 0 \\
1.8^{\mathrm{b}} \\
\pm 0.7 \\
75.1^{\mathrm{b}} \\
\pm 7.8^{\circ}\end{array}$ & $\begin{array}{c}30.3^{\mathrm{a}} \\
\pm 0.3^{\mathrm{ab}} \\
0.1^{\mathrm{ab}} \\
\pm 0.3^{\mathrm{b}} \\
20.1^{\mathrm{b}} \\
\pm 3.9^{\mathrm{a}} \\
99.8^{\mathrm{a}} \\
\pm 0.1\end{array}$ & $\begin{array}{c}29.9^{\mathrm{a}} \\
1.4^{\mathrm{ab}} \\
0.3^{\mathrm{a}} \\
\pm 0.9^{\mathrm{b}} \\
22.7^{\mathrm{b}} \\
\pm 13.1^{\mathrm{a}} \\
98.8^{\mathrm{a}} \\
\pm 1.5^{\mathrm{m}}\end{array}$ & & 22.87 & $<0.001$ \\
\hline Temperature & $\begin{array}{l}\text { Mean } \\
\text { Minimal } \\
\text { Maximal } \\
\mathrm{F}<8^{\circ} \mathrm{C} \\
\mathrm{F}<12^{\circ} \mathrm{C} \\
\mathrm{F}<16^{\circ} \mathrm{C} \\
\mathrm{F}<20^{\circ} \mathrm{C}\end{array}$ & $\begin{array}{c}16.7^{\mathrm{a}} \\
\pm 0.2 \\
1.2^{\mathrm{bc}} \\
\pm 0.4 \\
34.4 \\
\pm 0.5 \\
9.5^{\mathrm{a}} \\
\pm 0.3^{\mathrm{a}} \\
31.6^{\mathrm{a}} \\
\pm 0.7 \\
50.4^{\mathrm{a}} \\
\pm 0.7 \\
62.7^{\mathrm{ac}} \\
\pm 1.3\end{array}$ & 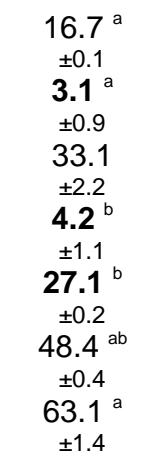 & $\begin{array}{c}17.0^{\mathrm{b}} \\
\pm 0.1^{\circ} \\
0.8^{\mathrm{c}} \\
\pm 0.5 \\
34.1 \\
\pm 2.1^{\mathrm{a}} \\
7.9^{\mathrm{a}} \\
\pm 0.2^{\circ} \\
28.0^{\mathrm{a}} \\
\pm 0.2^{\mathrm{b}} \\
48.0^{\mathrm{b}} \\
\pm 0.2^{\mathrm{a}} \\
59.5^{\mathrm{b}} \\
\pm 0.3^{\circ}\end{array}$ & $\begin{array}{c}17.0^{\mathrm{b}} \\
\pm 0.1^{\mathrm{b}} \\
1.9^{\mathrm{b}} \\
\pm 0.9 \\
32.9^{2} \\
\pm 2.6^{\mathrm{a}} \\
7.5^{\mathrm{a}} \\
\pm 0.7^{\mathrm{a}} \\
28.1^{\mathrm{a}} \\
\pm 0.5^{\mathrm{ab}} \\
48.3^{\mathrm{ab}} \\
\pm 0.3^{\mathrm{cb}} \\
59.9^{\mathrm{cb}} \\
\pm 0.7^{\circ}\end{array}$ & 31.80 & 12.13 & $\begin{array}{l}<0.001 \\
<0.001\end{array}$ \\
\hline \multicolumn{2}{|c|}{ Current $\mathrm{F}<0.25 \mathrm{~m} / \mathrm{s}$} & $\begin{array}{c}93.3 \\
\pm 6.9\end{array}$ & $\begin{array}{c}95.6 \\
\pm 4.5\end{array}$ & $\begin{array}{l}91.3 \\
\pm 10.4\end{array}$ & $\begin{array}{l}82.2 \\
\pm 15.7\end{array}$ & & 4.97 & 0.174 \\
\hline \multicolumn{2}{|c|}{$\%$ Emersion time } & $\begin{array}{c}0.0^{\mathrm{a}} \\
\pm 0\end{array}$ & $\begin{array}{c}30.9^{\mathrm{b}} \\
\pm 16.9\end{array}$ & $\begin{array}{c}32.9^{\mathrm{b}} \\
\pm 11.4\end{array}$ & $\begin{array}{l}13.0^{\mathrm{a}} \\
\pm 15.1\end{array}$ & 6.26 & & 0.002 \\
\hline \multicolumn{2}{|c|}{ Clam density (ind/m²) } & $\begin{array}{c}16.2^{\mathrm{ab}} \\
\pm 28.1\end{array}$ & $\begin{array}{l}6.3^{\mathrm{a}} \\
\pm 7.9\end{array}$ & $\begin{array}{l}51.4^{\mathrm{b}} \\
\pm 41.7\end{array}$ & $\begin{array}{c}23.9^{\mathrm{ab}} \\
\pm 18.6\end{array}$ & & 10.84 & 0.012 \\
\hline $\begin{array}{l}\text { Distance } \\
(\mathrm{km})\end{array}$ & $\begin{array}{l}\text { Leyre } \\
\text { Canal des Etangs }\end{array}$ & $\begin{array}{c}5.9^{\mathrm{ab}} \\
\pm 8.1 \\
9.8^{\mathrm{ab}} \\
\pm 8.1 \\
12.7^{\mathrm{a}} \\
\pm 1.9^{2}\end{array}$ & $\begin{array}{c}13.8^{\mathrm{a}} \\
\pm 1.1^{\mathrm{ab}} \\
8.2^{\mathrm{ab}} \\
\pm 0.9 \\
\mathbf{3 . 0} \mathbf{0}^{\mathrm{b}} \\
\pm 1.0^{0}\end{array}$ & $\begin{array}{c}12.4^{\mathrm{ab}} \\
\pm 1.3 \\
3.3^{\mathrm{a}} \\
\pm 1.3 \\
9.6^{\mathrm{a}} \\
\pm 0.4\end{array}$ & $\begin{array}{l}8.2^{b} \\
\pm 4.3 \\
8.2^{b} \\
\pm 4.1 \\
9.5^{a} \\
\pm 1.9\end{array}$ & & 22.06 & $<0.001$ \\
\hline
\end{tabular}


Table 3. Different characteristics of the environment in both axes (Fig. 1). Student $t$-test $(t$ value) was performed to compare values between axes. Values that are different $(\mathrm{p}<0.05)$ are in bold and italic.

\begin{tabular}{|c|c|c|c|c|c|}
\hline & & Axis 1 & Axis 2 & $\mathrm{t}$ & $p$ \\
\hline \multirow[t]{4}{*}{ Sediment } & Median $(\mu \mathrm{m})$ & 131.9 & 127.4 & 0.20 & 0.838 \\
\hline & Silt $(\%)$ & 23.5 & 32.1 & -2.12 & 0.041 \\
\hline & Organic matter (\%) & 4.3 & 7.3 & -3.11 & 0.004 \\
\hline & Seagrass cover (\%) & 44.6 & 51 & -0.60 & 0.550 \\
\hline \multirow[t]{4}{*}{ Salinity } & Mean & 29.5 & 30.9 & -1.38 & 0.178 \\
\hline & $F<13$ & 2.6 & 0.8 & 1.02 & 0.315 \\
\hline & $F<28$ & 25.2 & 15.2 & 1.49 & 0.144 \\
\hline & $\mathrm{F}<34$ & 91.2 & 92.3 & -0.27 & 0.790 \\
\hline \multirow[t]{7}{*}{ Temperature } & Mean & 16.9 & 16.9 & 0.30 & 0.765 \\
\hline & Minimal & 2.5 & 1.7 & 2.28 & 0.029 \\
\hline & Maximal & 32.1 & 33.7 & -2.05 & 0.048 \\
\hline & $\mathrm{F}<8^{\circ} \mathrm{C}$ & 6.6 & 6.9 & -0.39 & 0.700 \\
\hline & $\mathrm{F}<12^{\circ} \mathrm{C}$ & 28.2 & 27.9 & 0.69 & 0.489 \\
\hline & $\mathrm{F}<16^{\circ} \mathrm{C}$ & 48.6 & 48.3 & 1.33 & 0.191 \\
\hline & $\mathrm{F}<20^{\circ} \mathrm{C}$ & 61.3 & 60.9 & 0.57 & 0.573 \\
\hline \multicolumn{2}{|c|}{ Current $\mathrm{F}<0.25 \mathrm{~m} / \mathrm{s}$} & 85.3 & 91.9 & -1.53 & 0.135 \\
\hline \multicolumn{2}{|c|}{$\%$ Emersion time } & 11.4 & 28.3 & -3.16 & 0.003 \\
\hline \multicolumn{2}{|c|}{ Clam density (ind $/ \mathrm{m}^{2}$ ) } & 17.6 & 27.7 & -1.11 & 0.273 \\
\hline \multirow{3}{*}{$\begin{array}{l}\text { Distance } \\
(\mathrm{km})\end{array}$} & Leyre & 7.2 & 13.3 & -5.10 & $<0.001$ \\
\hline & Canal des Etangs & 10.9 & 4.5 & 7.83 & $<0.001$ \\
\hline & Atlantic Ocean & 8.4 & 7.4 & 0.83 & 0.414 \\
\hline
\end{tabular}


Table 4. Correlation between 1) Perkinsus concentration, Brown Muscle Disease (BMD) prevalence, BMD's Muscle Print Index (MPI) and 2) different parameters of the environment $(\mathrm{N}=34)$. Significant correlations $(\mathrm{p}<0.05)$ are in bold and italic.

$\mathrm{R}=$ Pearson correlation coefficient

\begin{tabular}{|c|c|c|c|c|c|c|c|}
\hline & & \multirow{2}{*}{\multicolumn{2}{|c|}{$\begin{array}{l}\text { Perkinsus concentration } \\
\quad \text { (Cells/g of gills) }\end{array}$}} & \multirow{2}{*}{\multicolumn{4}{|c|}{ Prevalence (\%) }} \\
\hline & & & & & & & \\
\hline & & $\mathrm{R}$ & $p$ & $\mathrm{R}$ & $p$ & $\mathrm{R}$ & $p$ \\
\hline \multirow[t]{4}{*}{ Sediment } & Median $(\mu \mathrm{m})$ & -0.04 & 0.829 & -0.27 & 0.141 & -0.28 & 0.119 \\
\hline & Silt (\%) & 0.25 & 0.149 & 0.45 & 0.010 & 0.39 & 0.025 \\
\hline & Organic matter (\%) & 0.35 & 0.040 & 0.52 & 0.003 & 0.42 & 0.015 \\
\hline & Seagrass cover (\%) & 0.09 & 0.594 & 0.07 & 0.713 & -0.35 & 0.051 \\
\hline \multirow[t]{4}{*}{ Salinity } & Mean & 0.29 & 0.101 & -0.10 & 0.580 & -0.26 & 0.145 \\
\hline & $\mathrm{F}<13$ & -0.31 & 0.073 & 0.08 & 0.672 & -0.03 & 0.865 \\
\hline & $\mathrm{F}<28$ & -0.27 & 0.127 & 0.07 & 0.681 & 0.29 & 0.098 \\
\hline & $\mathrm{F}<34$ & 0.03 & 0.875 & 0.37 & 0.039 & 0.72 & $<0.001$ \\
\hline \multirow[t]{7}{*}{ Temperature } & Minimal & -0.29 & 0.093 & -0.37 & 0.034 & -0.46 & 0.008 \\
\hline & Maximal & 0.29 & 0.090 & 0.12 & 0.514 & -0.02 & 0.900 \\
\hline & Mean & 0.09 & 0.614 & 0.12 & 0.6644 & 0.66 & $<0.001$ \\
\hline & $\mathrm{F}<8^{\circ} \mathrm{C}$ & 0.00 & 0.990 & 0.32 & 0.071 & 0.65 & $<0.001$ \\
\hline & $\mathrm{F}<12^{\circ} \mathrm{C}$ & -0.26 & 0.131 & 0.18 & 0.330 & 0.21 & 0.245 \\
\hline & $\mathrm{F}<16^{\circ} \mathrm{C}$ & -0.35 & 0.043 & -0.00 & 0.987 & -0.24 & 0.176 \\
\hline & $\mathrm{F}<20^{\circ} \mathrm{C}$ & -0.17 & 0.344 & -0.23 & 0.213 & -0.73 & $<0.001$ \\
\hline \multicolumn{2}{|c|}{ Current $F<0.25 \mathrm{~m} / \mathrm{s}$} & 0.09 & 0.626 & -0.16 & 0.390 & -0.20 & 0.270 \\
\hline \multicolumn{2}{|c|}{$\%$ Emersion time } & 0.34 & 0.048 & 0.13 & 0.491 & 0.03 & 0.875 \\
\hline \multicolumn{2}{|c|}{ Clam density (ind/m²) } & 0.10 & 0.569 & -0.12 & 0.502 & 0.37 & 0.037 \\
\hline \multirow{3}{*}{$\begin{array}{l}\text { Distance } \\
(\mathrm{km})\end{array}$} & Leyre & 0.43 & 0.011 & 0.28 & 0.114 & -0.28 & 0.113 \\
\hline & Canal des Etangs & -0.51 & 0.002 & -0.60 & $<0.001$ & -0.20 & 0.260 \\
\hline & Atlantic Ocean & -0.14 & 0.422 & 0.20 & 0.264 & 0.62 & $<0.001$ \\
\hline
\end{tabular}


Fig. 1. Principal Component Analysis (PCA) based on 21 environmental factors (A) from 33 stations (B). Four groups can be separated. Organic Matter content in the sediment contributed to Axis 1, while salinity and temperature contributed to Axis 2. Group 1: blue; Group 2: green; Group 3: violet; and Group 4: red. White: No values

Disks with the above-mentioned colours represent stations where bivalves were collected while yellow disks represent stations that were surveyed within ARCHYD network in order to obtain ground-truth values of salinity and temperature for model validation. Black disk situates Eyrac tide gauge to calibrate sea surface height with the model and to deduce emersion time.

Fig. 2. Abundance of Perkinsus olseni (cells/g (fresh weight) in gills) per station in Arcachon Bay.

Fig. 3. Brown Muscle Disease (BMD) prevalence per station in Arcachon Bay. Mean BMD prevalence per axis (i.e. subarea) is mentioned.

Fig 4. Correspondence Analysis discriminating the 34 stations harbouring cockles in relation to trematode species in cockles (A) and different assemblages of trematodes in cockles from this Correspondence Analysis (B). Dominant species are indicated and discriminated by different colours. Stations with no characteristic trematode assemblage are in green, 
Figure 1

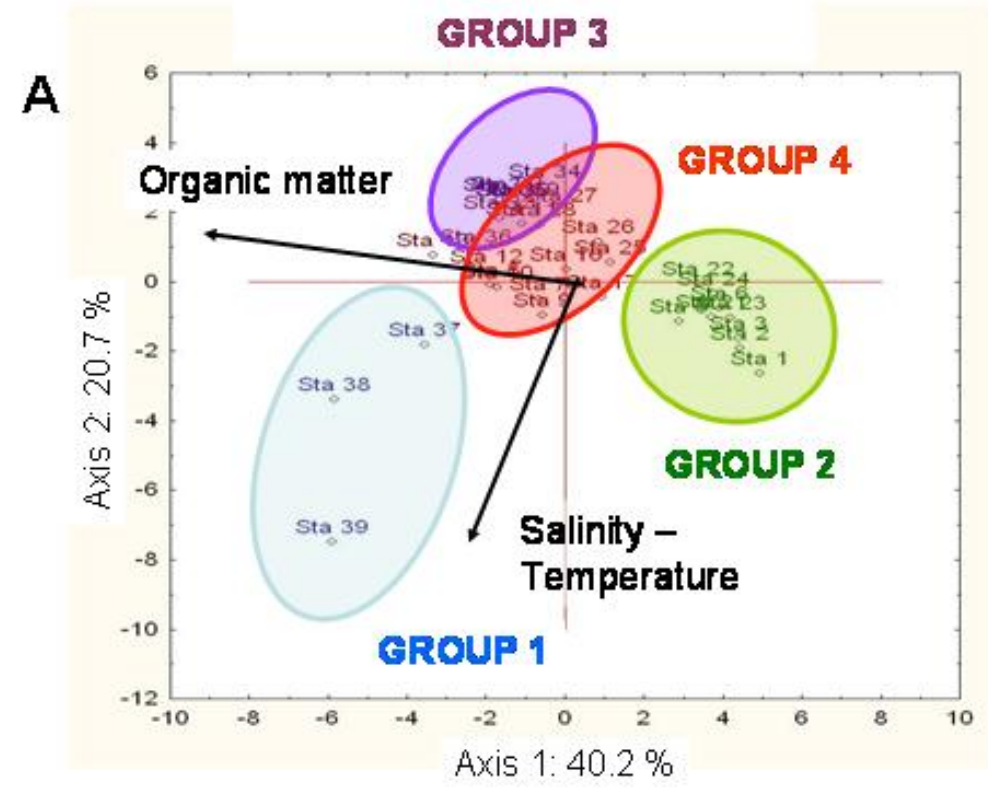

B

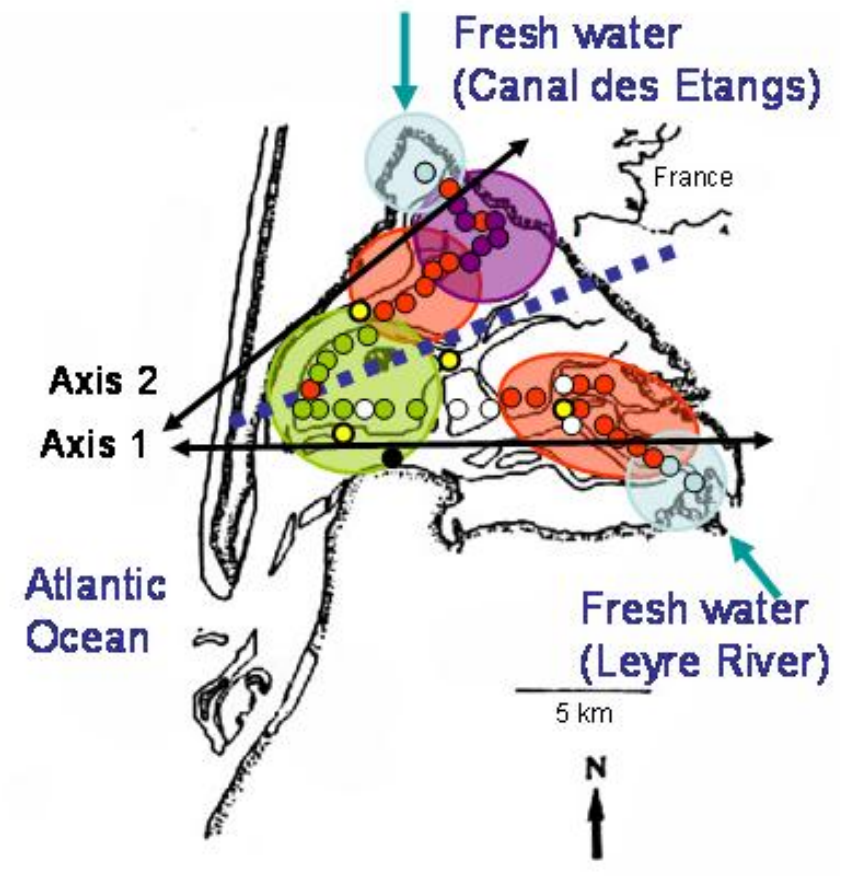


Figure 2
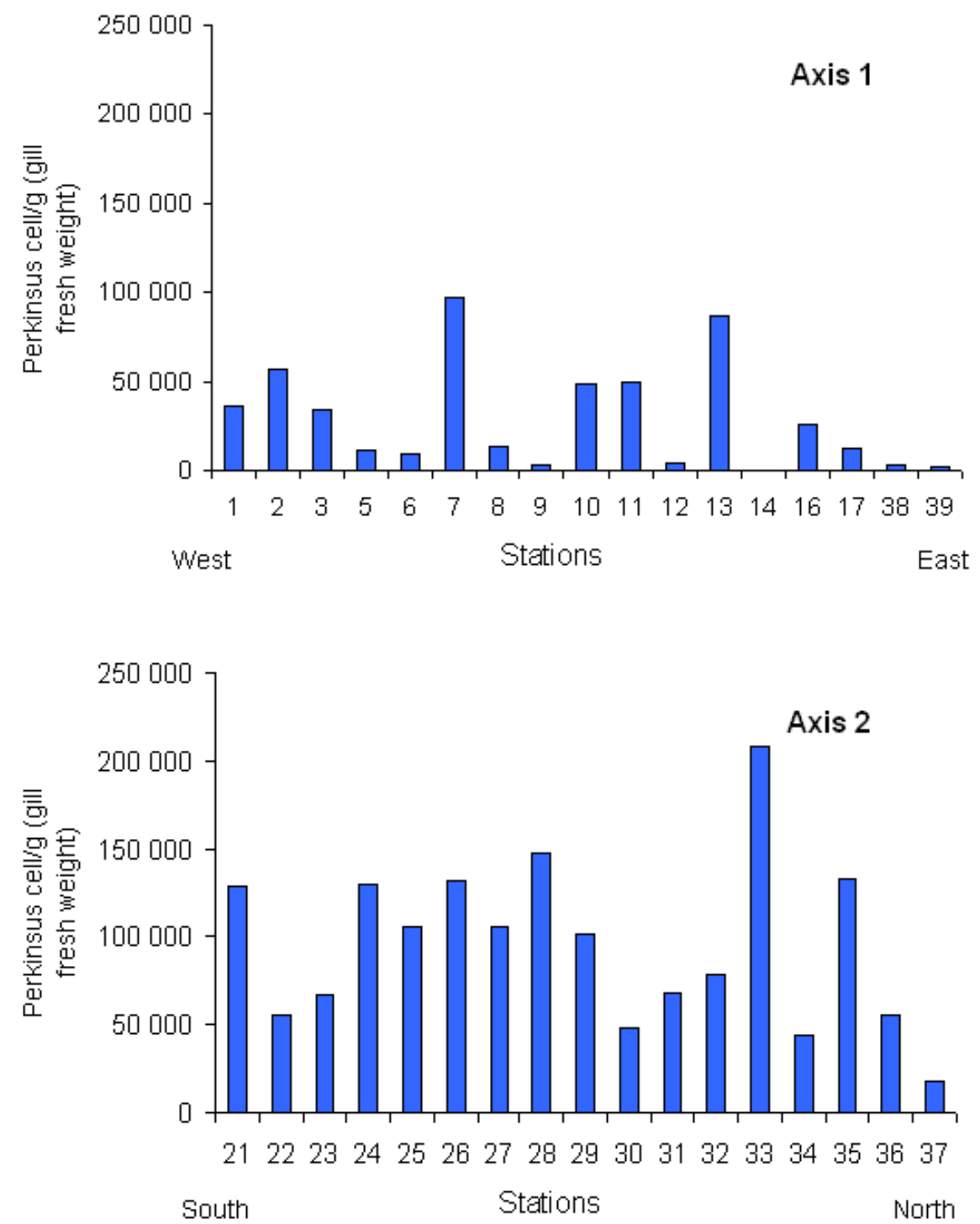
Figure 3

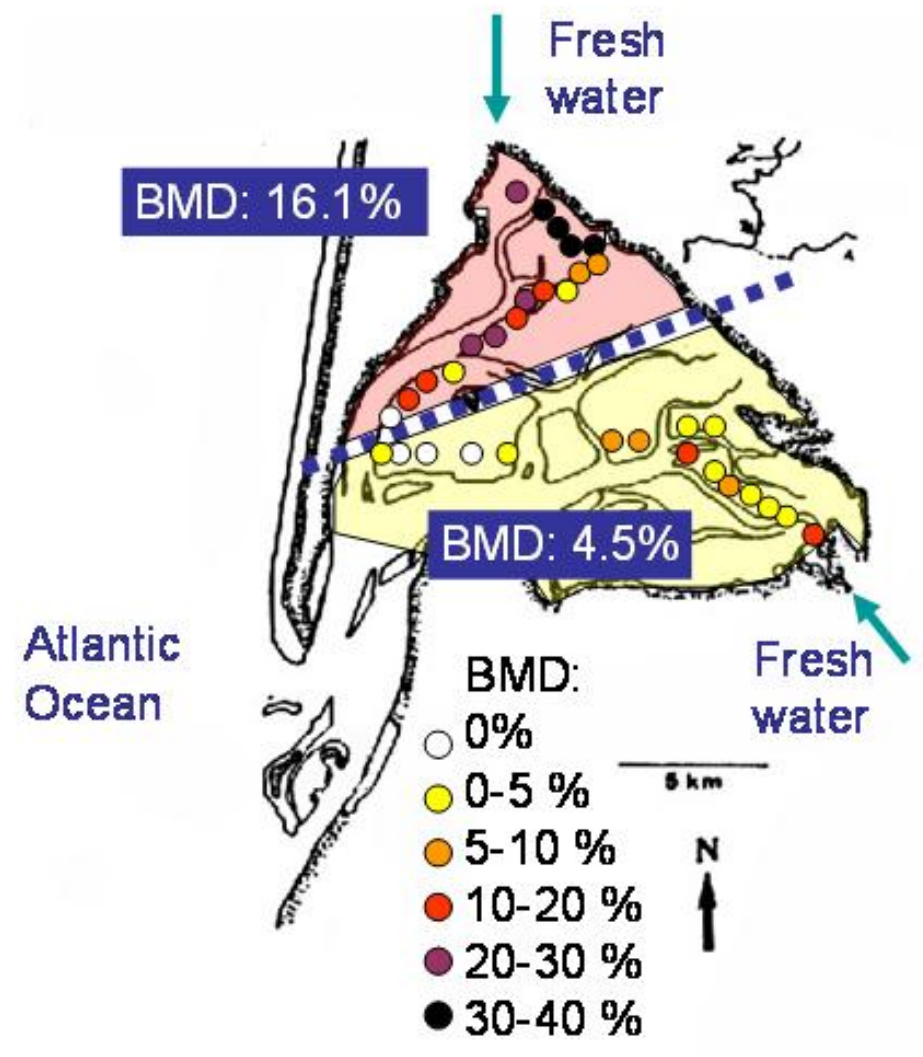


Figure 4

A

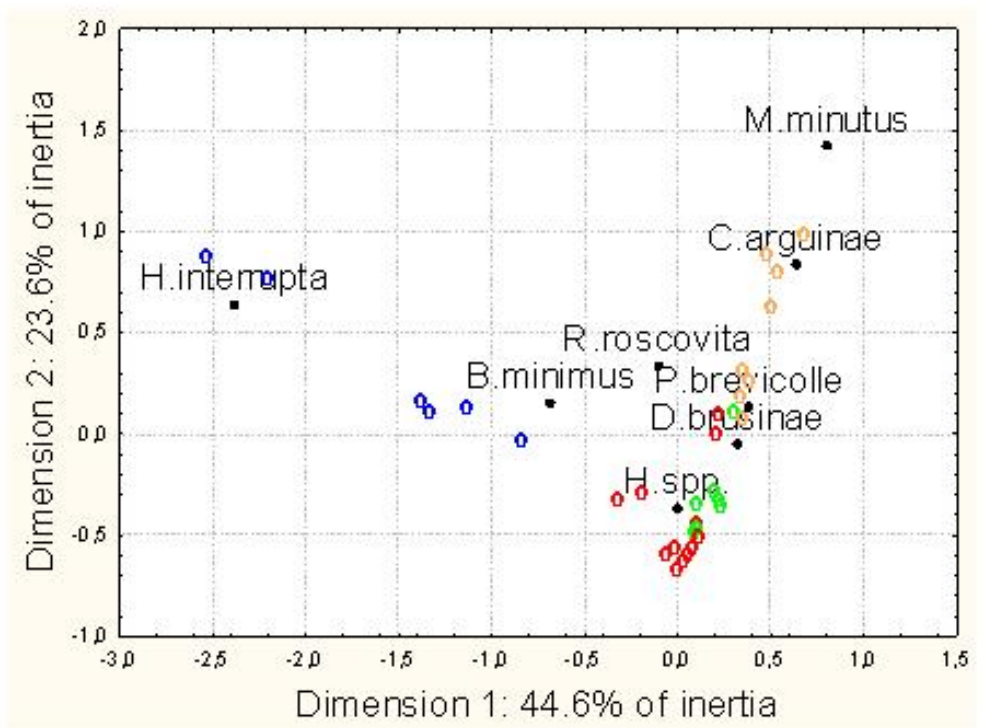

B

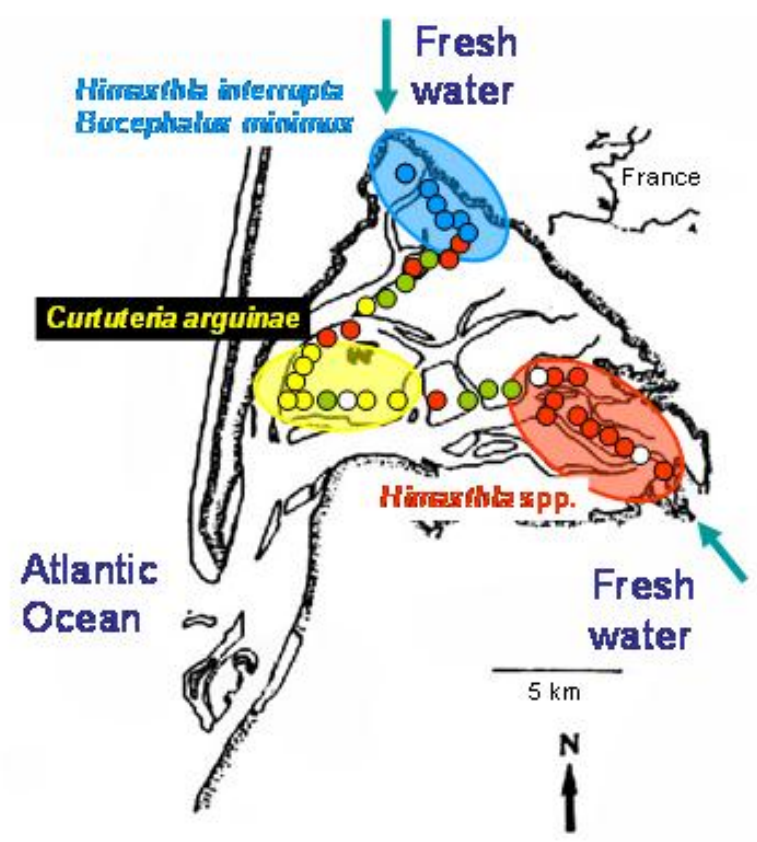

